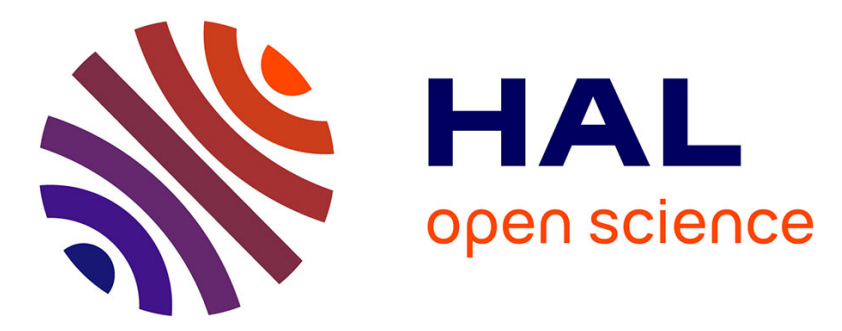

\title{
Physical and chemical characterization of automotive shredder residues
}

\author{
David Lanoir, Gwenael Trouve, Lucien Delfosse, Daniel Froelich, A. \\ Kassamaly
}

\section{- To cite this version:}

David Lanoir, Gwenael Trouve, Lucien Delfosse, Daniel Froelich, A. Kassamaly. Physical and chemical characterization of automotive shredder residues. Waste Management and Research, 1995, 15, pp.267276. hal-01205605

\section{HAL Id: hal-01205605 \\ https://hal.science/hal-01205605}

Submitted on 5 Dec 2016

HAL is a multi-disciplinary open access archive for the deposit and dissemination of scientific research documents, whether they are published or not. The documents may come from teaching and research institutions in France or abroad, or from public or private research centers.
L'archive ouverte pluridisciplinaire HAL, est destinée au dépôt et à la diffusion de documents scientifiques de niveau recherche, publiés ou non, émanant des établissements d'enseignement et de recherche français ou étrangers, des laboratoires publics ou privés. 


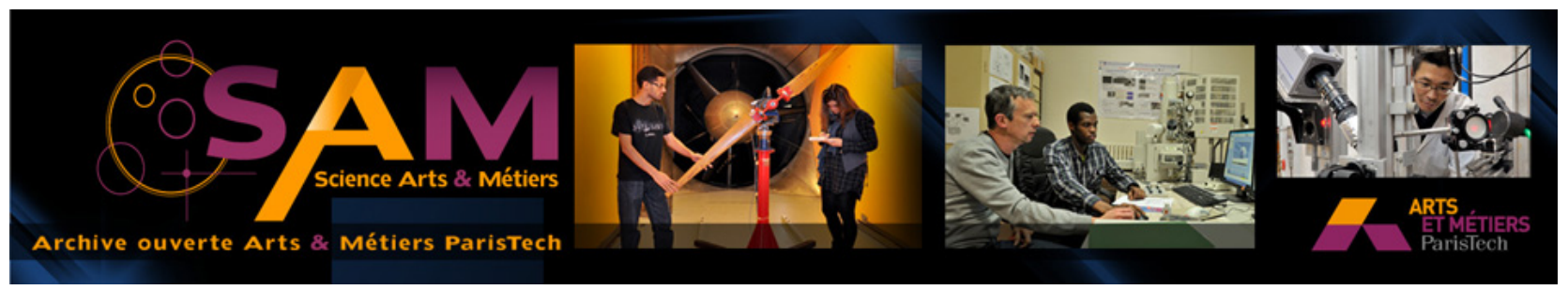

\section{Science Arts \& Métiers (SAM)}

is an open access repository that collects the work of Arts et Métiers ParisTech researchers and makes it freely available over the web where possible.

This is an author-deposited version published in: http://sam.ensam.eu

Handle ID: .http://hdl.handle.net/10985/10179

\section{To cite this version :}

DAVID LANOIR, GWENAEL TROUVE, LUCIEN DELFOSSE, DANIEL FROELICH, AMINA KASSAMALY - Physical and chemical characterization of automotive shredder residues - Waste management and research - Vol. 15, p.267-276 - 1995 


\title{
PHYSICAL AND CHEMICAL CHARACTERIZATION OF AUTOMOTIVE SHREDDER RESIDUES
}

\author{
D. Lanoir ${ }^{1}$, G. Trouvé $e^{1,2}$, L. Delfosse ${ }^{1}$, D. Froelich ${ }^{3}$ and A. Kassamaly ${ }^{3}$ \\ ${ }^{1}$ Ecole Nationale Supérieure de Chimie de Mulhouse, Laboratoire Gestion des Risques \\ et Environnement, 25, rue de Chemnitz, 68100 Mulhouse, France and ${ }^{3}$ Renault S.A., \\ Projet Recyclage, 160, Avenue de Versailles, 75016 Paris, France
}

\begin{abstract}
Car manufacturers recycle many of the materials from wrecked vehicles, but the disposal of the lighter components is increasingly difficult. The high cost of landfill is making the option of incineration more attractive, as it reduces the mass and the volume of the waste. Energy recovery is also possible. This paper examines those properties of automotive shredder residues (ASR) which are relevant to the formation of pollutants during incineration.

The higher specific e nergy of A SR w as f ound to be $19,000 \mathrm{~kJ} \mathrm{k} \mathrm{g}^{-1}$ a nd the ash content $38 \%$, which indicate that it is a suitable fuel for municipal incinerators or cement kilns. However, it is very heterogeneous, as the low density fraction is mainly composed of plastics, with smaller amounts of metallic pieces, rubber, glass and wood. The macroscopic composition of a representative sample of ASR was determined. The metal and the chlorine contents were analysed by special techniques and were found to be $22 \%$ and $3.5 \%$, respectively of the fraction. Laboratory-scale incineration trials of ASR are now planned.
\end{abstract}

Key Words-Automotive waste, incineration, characterization, ash content, caloric value and metals.

\section{Introduction}

In France, there are now 23 million cars on the roads. About $8 \%$ of them (two million) become unroadworthy each year and need to be disposed of. They include both automotive wrecks or end of life vehicles.

Since the 1970s, the French procedure for the recycling of these automotive wrecks could be summarized according to the main phases described in Fig. 1 (De Macedo 1984):

(1) First of all, batteries are removed and all fluids are recycled.

(2) Afterwards, the wrecks are mechanically reduced in size to produce automotive shredder residues (ASR).

(3) A first fraction of ASR, which consists primarily of low-density plastic pieces, is first separated from the shreds by an air separator. Some other materials such as glass, wood, sand, dust and fine metallic particles may also be carried away with the plastics. This fraction is generally called fluff (fraction No. 1).

(4) Later, ferrous metals are extracted from the remaining shreds by passing them 


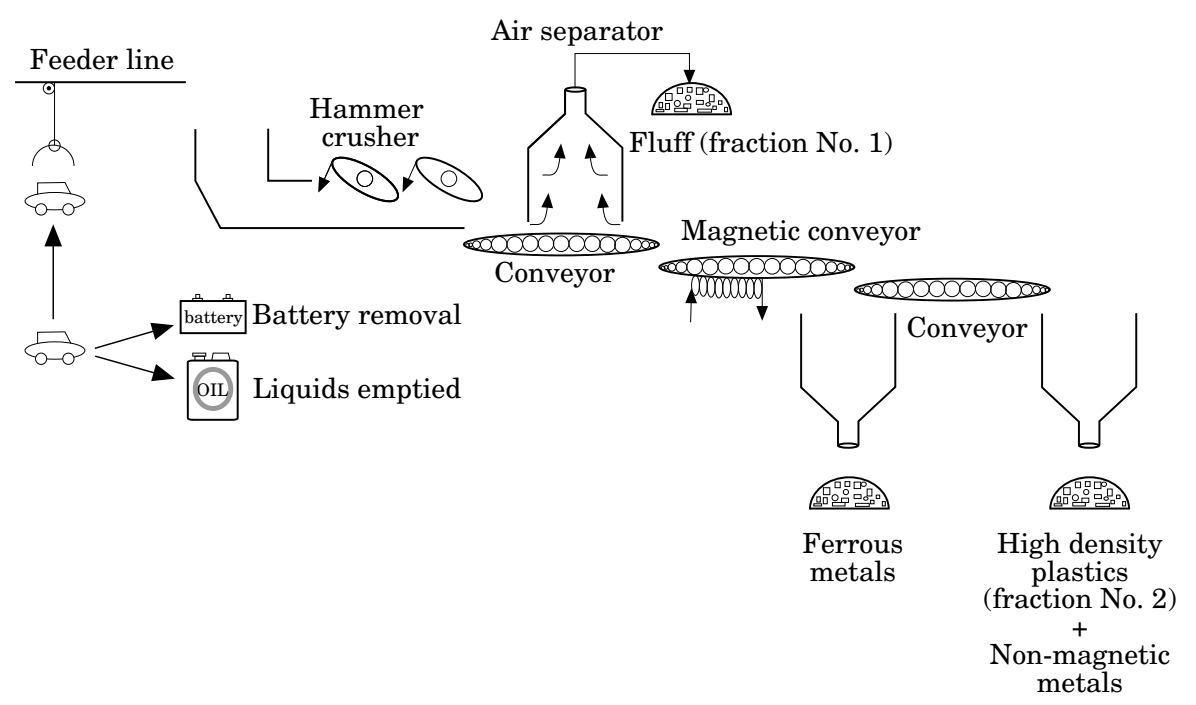

Fig. 1. Automotive wrecks elimination process.

through a magnetic field. Each year, 1.2 million tonnes of scrap iron are obtained using this technique and re-used in steel mills to produce steel.

(5) The non-magnetic part of the shreds, containing some plastic pieces with a high density (primarily rubber) and some non-magnetic metals such as aluminium, copper and zinc, is sorted by induction. The metallic part is separated from the organic matter and can be recycled in zinc coating shops. The organic product, which constitutes the second fraction of ASR (fraction No. 2), has a high specific energy $\left(25000 \mathrm{~kJ} \mathrm{~kg}^{-1}\right.$ ) and can be used as fuel in several industries.

(6) Fractions No. 1 (low-density plastics) and No. 2 (high-density plastics) together make up $25 \%$ of a vehicle's weight and are generally called ASR.

Up to now, 350 to 400 thousand tonnes of ASR are disposed of in landfills every year. Land disposal will become impossible in the near future due to a lack of space.

In order to reduce pollution, resource recovery from waste has become much more important in recent years. The French and European regulations make the manufacturers responsible for the ultimate fate of their products (French Framework Agreement 1993). European countries such as Italy, Spain and Great Britain are on the way to adopting the French Framework Agreement. France was chosen by the European Union as the pilot to solve the problems associated with the disposal of the automotive shredder residues. Car manufacturers are increasing the portion of recycled materials in their vehicles. Previously, $75 \%$ of vehicular scrap was recycled, but this figure has now risen to $85-90 \%$.

Another solution for waste treatment appears to be incineration. It would both reduce the volume of waste and contribute to energy recovery. Incineration of waste at two temperatures will be investigated: at $850^{\circ} \mathrm{C}$ in municipal waste incinerators and at $1100^{\circ} \mathrm{C}$ in cement plants.

\section{Aims}

Incineration of ASR presents some advantages over other treatment methods. At $850^{\circ} \mathrm{C}$, this process could be carried out in municipal waste incinerators and would supplement 


\section{Physical and chemical characterization of automotive shredder residues}

district heating supplies. In cement works, the addition of ASR to the kiln would be fuel efficient: the energy released by combustion would help in stabilizing the temperature. Moreover, a temperature of about $1450^{\circ} \mathrm{C}$ is high enough to decompose organic pollutants. Calcium carbonate and clay which constitute the clinker in the preparation of cement would be able to trap metals present in the waste as well as acid gaseous effluents. However, the use of ASR in municipal or industrial incineration plants needs to conform to safety and emission regulations. The study of the ASR composition therefore appears to be very important for environmental risk assessment.

Before introducing ASR as a fuel into municipal incinerators or industrial works, it is necessary to determine their physical and chemical characteristics and to estimate the levels and types of pollution which would be emitted during ASR combustion.

In this project, the nature and the distribution of the constituents of ASR were determined, i.e. the physical properties, the specific energy and ash content, and the elemental chlorine and metal contents.

\section{Experimental work}

\subsection{Sampling}

During the crushing process of an automotive wreck, two kinds of ASR were separated, i.e. fractions No. 1 and 2. The sample studied was obtained from the first fraction of ASR and sized in the range 5 to $20 \mathrm{~mm}$. The fraction studied was obtained by crushing a representative sample of obsolete vehicles selected randomly from a scrapyard (Lanoir 1994).

\subsection{Methods}

Initially, it appeared that the ASR were too heterogeneous to allow a direct study. Consequently, it was decided to determine its macroscopic composition.

\subsubsection{Macroscopic composition determination}

A sample of $250 \mathrm{~g}$ was sorted out of a 50-litre bag of fluff. The ASR were divided into four groups: plastics, rubber, metals and others which were also subdivided into families. Table 1 gives the constituents which were visually identified during this macroscopic composition determination.

Once the macroscopic composition was known (see section 4, Results and discussion), it was possible to study separately each kind of constituent and, with the weight distribution, to obtain a total result.

\subsubsection{Specific energy determination}

One gram of each kind of sorted constituent (plastics, rubber, metals and others) was placed in a LECO AC-300 automatic calorimeter for specific energy determination. Each value given in section 4 is the average of five experiments. This apparatus gives results in terms of high specific energy, and since the hydrogen content of each tested sample was unknown, it was impossible to obtain the low specific energy from these measurements. 


\section{Lanoir et al.}

TABLE 1

Selected groups and families in macroscopic composition determination

\begin{tabular}{ll}
\hline Groups & Families \\
\hline Plastics & $\begin{array}{l}\text { Rigid plastics } \\
\text { Coating and textile plastics } \\
\text { Foams }\end{array}$ \\
& $\begin{array}{l}\text { Simple } \\
\text { Textile reinforced } \\
\text { Metal reinforced }\end{array}$ \\
Rubber & Magnetics \\
& Non magnetics \\
Connecting wires (copper, plastic sheath) & Wood \\
Metals & Glass \\
& Stone and earth \\
\hline
\end{tabular}

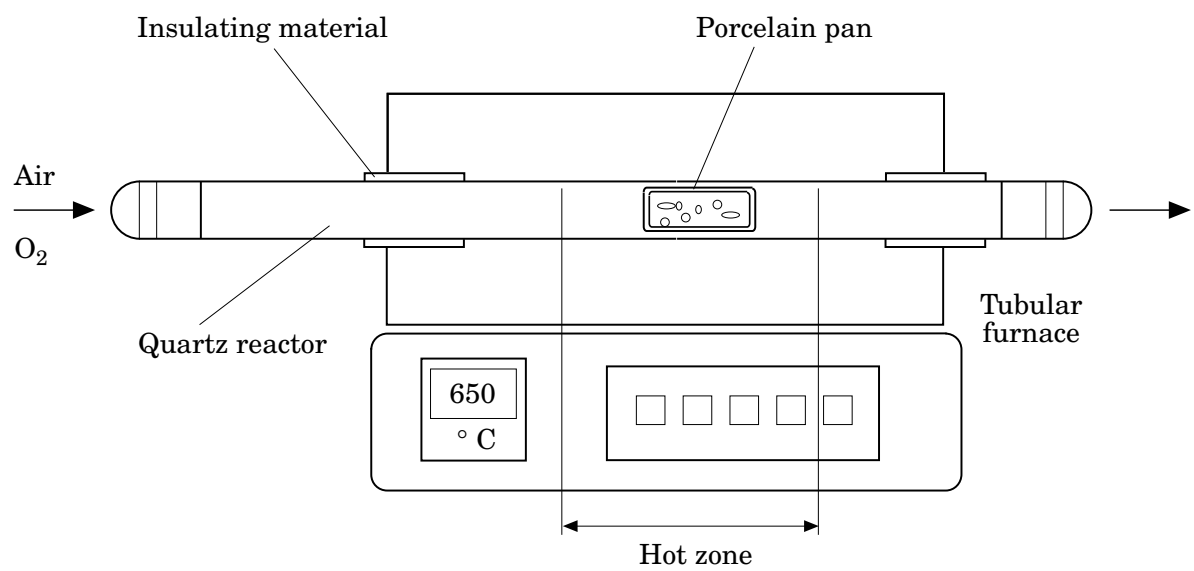

Fig. 2. Apparatus for the determination of ash content.

\subsubsection{Ash content determination}

Ash content was determined by using the following method (see Fig. 2). A sample (1 g of each kind of sorted constituent) was weighed in a porcelain pan and placed in a tubular quartz reactor which was set in the middle of the furnace's hot zone. Figure 3 shows the variation of experimental conditions as a function of time (atmosphere and temperature) during the experiment.

The experiment proceeded in two steps:

(1) The temperature was raised from ambient to $650^{\circ} \mathrm{C}$ while the atmosphere was slowly enriched with oxygen.

(2) An isotherm at $650^{\circ} \mathrm{C}$ was maintained for 15 minutes.

The resulting mass weighed in the porcelain pan gave the ash content of the sample. 


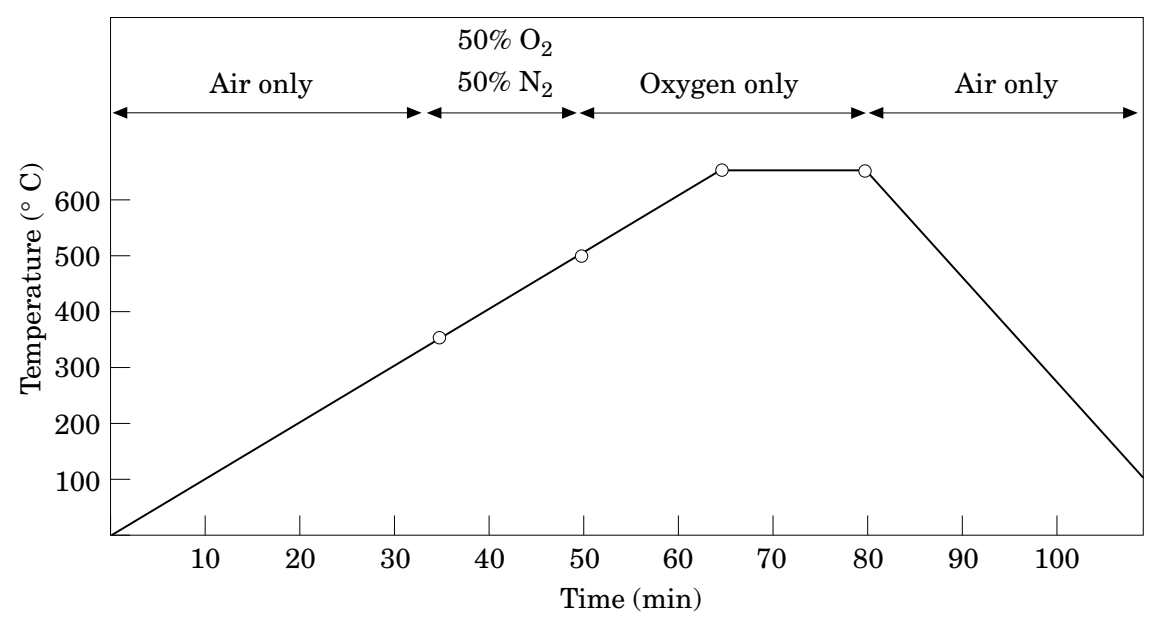

Fig. 3. Variation of experimental conditions during ash content determination.

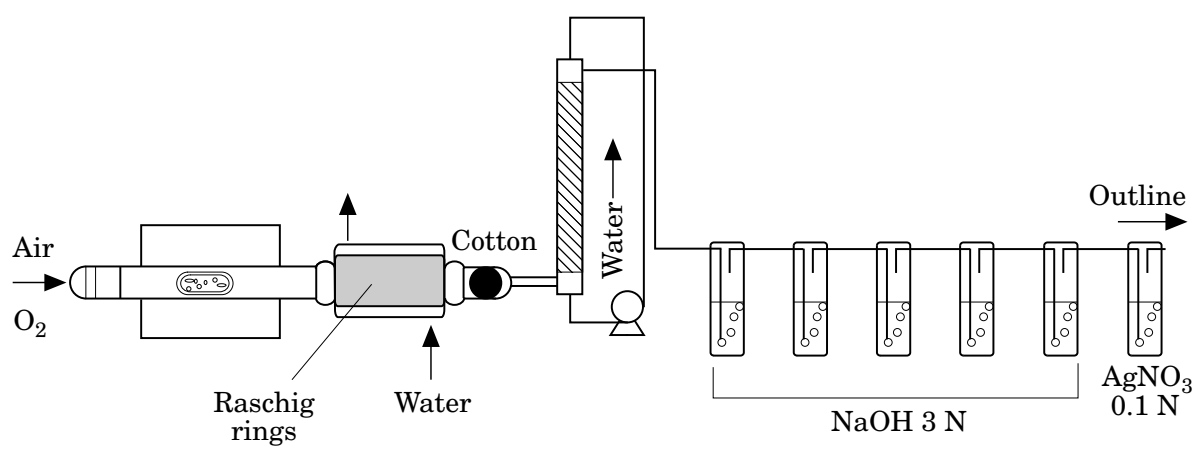

Fig. 4. Apparatus for the determination of chlorine content.

Each content given in section 4 is the average of three measurements. This method of slow oxygen enrichment was used to prevent violent deflagration. In fact, the quantity of volatile compounds was important in our experiments. For safety reasons, temperatures had to be lower than the limit of explosion of the system.

\subsubsection{Chlorine content determination}

The chlorine content of the material was determined by using the same apparatus as that used to obtain the ash content, as shown in Fig. 4. The method of oxygen enrichment described previously was used for the determination of chlorine content:

(1) The combustion gases in which most of the organic chlorine gave rise to hydrogen chloride were passed through a washing tower with counter-current water flow, and then through washing bottles containing a sodium hydroxide solution $\left(1 \mathrm{moll}^{-1}\right)$ in order to trap the hydrogen chloride.

(2) Tar and soot were trapped before passing through the washing tower by using a cooler, filled with Raschig rings and a cotton ball. After the reaction, the cotton ball 
and Raschig rings were washed with toluene. The toluene solution was then concentrated by using a rotary evaporator. Tar and soot were burned out in the same experimental device, from $20^{\circ} \mathrm{C}$ to $850^{\circ} \mathrm{C}$, under an air atmosphere to quantify their chloride contents.

(3) Ashes containing mineral chlorine were solubilized in fuming nitric acid for three hours at $120^{\circ} \mathrm{C}$.

Using this procedure, all the chlorine contained in the original sample before its destruction was present as chloride ion in solution.

Spectrometric titration of the chloride was performed using a Flow Injection Analysis Spectrometer FIAstar 5001. The colorimetric principle is based on the following reaction:

$$
3 \mathrm{Hg}(\mathrm{SCN})_{2}+2 \mathrm{Fe}^{3+}+6 \mathrm{Cl}^{-} \rightarrow 2 \mathrm{Fe}(\mathrm{SCN})_{3}+3 \mathrm{HgCl}_{2}
$$

$\mathrm{Fe}(\mathrm{SCN})_{3}$ is a red complex which presents a maximum absorbance at $507 \mathrm{~nm}$.

\subsubsection{Heavy metal content determination}

For the determination of the heavy metal contents, the method used is shown in Fig. 5.

The raw sample was attacked with aqua regia (three parts of hydrochloric acid $24 \%$ to one part of nitric acid $32 \%$ ). The mixture was maintained at $100^{\circ} \mathrm{C}$ for $6 \mathrm{~h}$ to dissolve metallic pieces mixed with plastics and rubber as well as metallic dust such as iron oxide.

The solution was separated from the organic residue under vacuum filtration. The solid residue was mineralized by a second acid attack; highly concentrated sulphuric acid and nitric acid were used respectively to treat the organic matter $\left(30 \mathrm{~min}\right.$ at $\left.200^{\circ} \mathrm{C}\right)$ and complete the mineralization $\left(6 \mathrm{~h}\right.$ at $\left.120^{\circ} \mathrm{C}\right)$. During this second acid attack, metallic components used as additives in polymeric materials were also dissolved. Using only nitric acid would have been dangerous, since some organic nitrous compounds are explosive (Lenga et al. 1993).

Some drops obtained after aqua regia attack were poured onto two ashless filters. They were tested on an X-ray Fluorescence spectrometer PHILIPS PV9500 (with Rhodium anti-cathode X-ray generator) leading to the identification of the metals present in the solutions. Metallic elements exhibited by X-ray fluorescence were then searched quantitatively using air-acetylene flame atomic absorption on a VARIAN TECHTRON A.A.6.

\section{Results and discussion}

\subsection{Macroscopic composition determination}

The results are presented in Fig. 6. Some selected families do not appear for two reasons:

(1) The group itself (group "Others" in Fig. 6) is so small that the families of this group do not represent a significant part of the total material.

(2) Within a significant group (group "Rubber" in Fig. 6), some families can be considered negligible as compared to others.

The data in Fig. 6 show that the fraction No. 1 of ASR is essentially composed of plastics. Rubber is found in bigger quantities in fraction No. 2. The non-negligible 


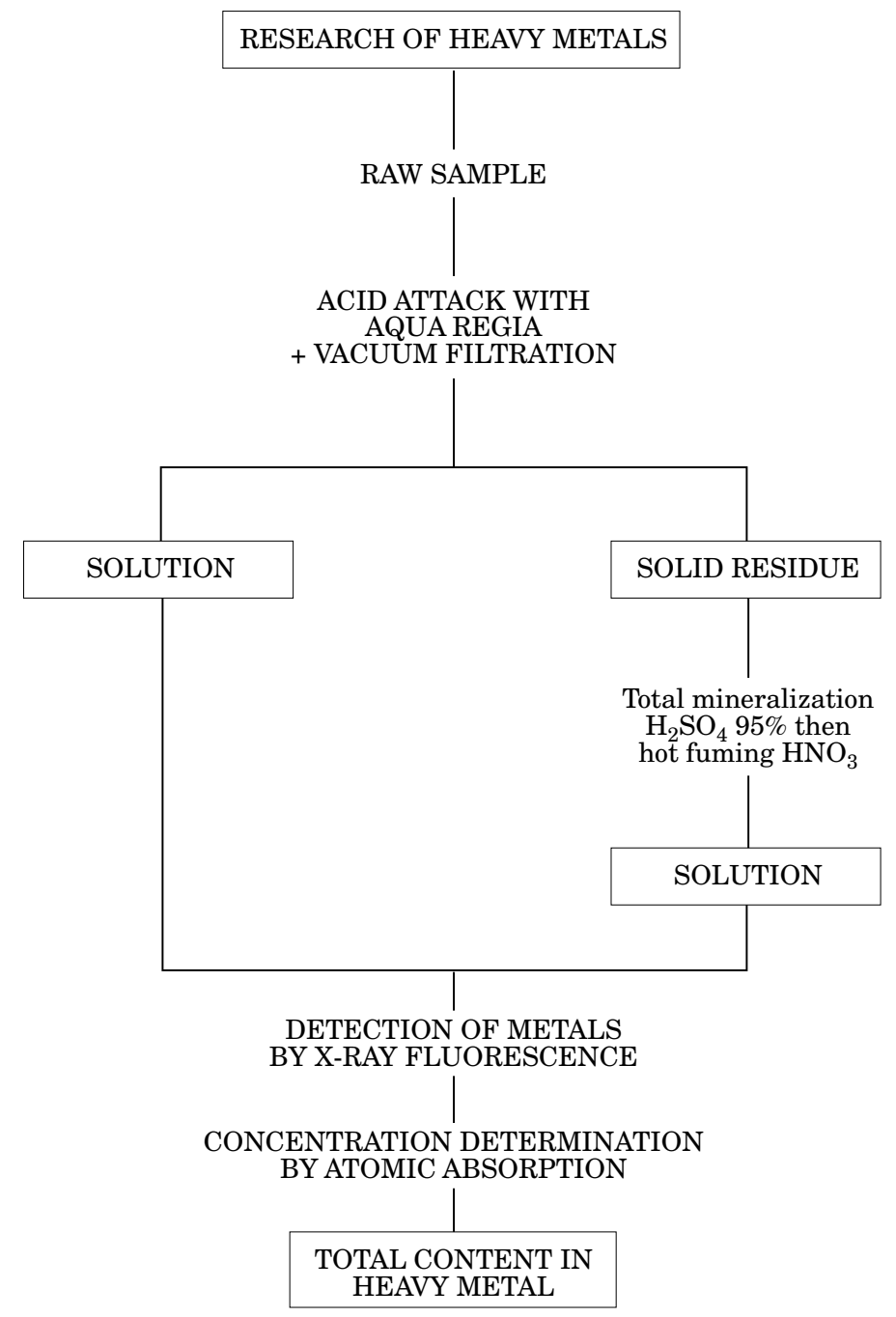

Fig. 5. Procedure for the heavy metal determination.

\section{PLASTICS : 83.1}

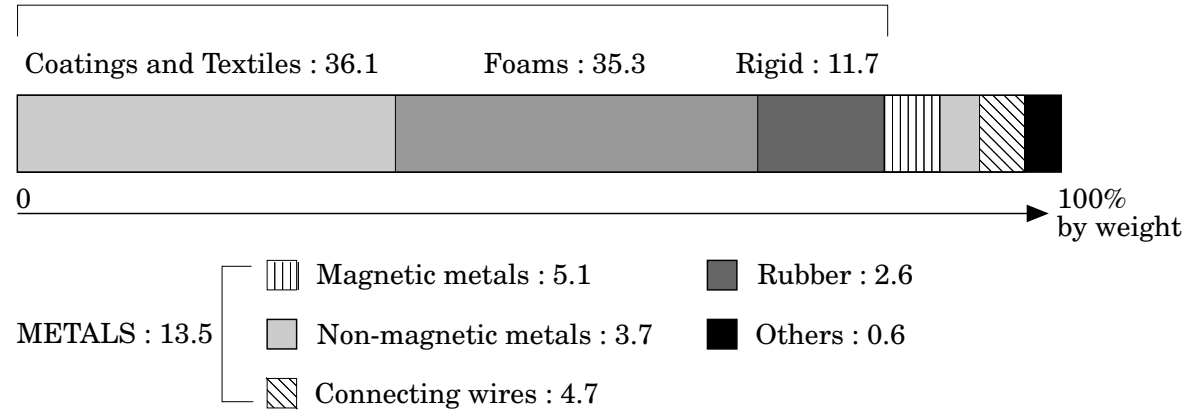

Fig. 6. Results of the macroscopic determination. 


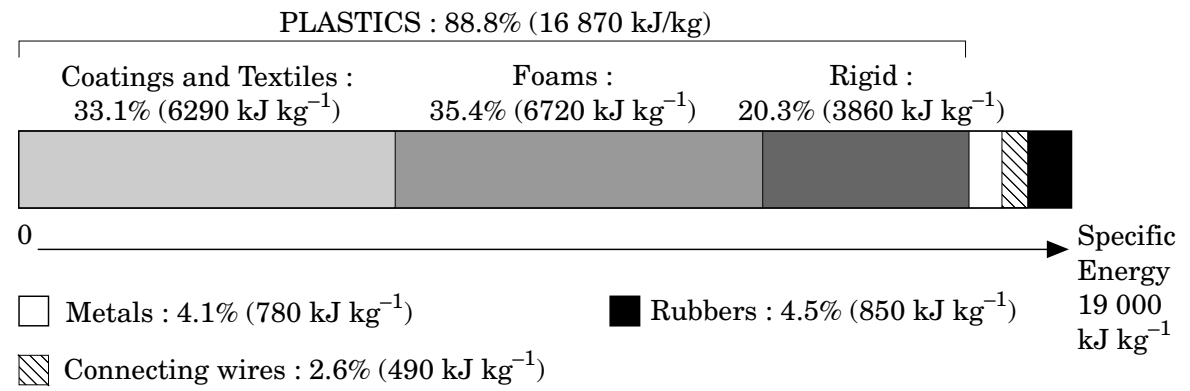

Fig. 7. Results of the specific energy determination.

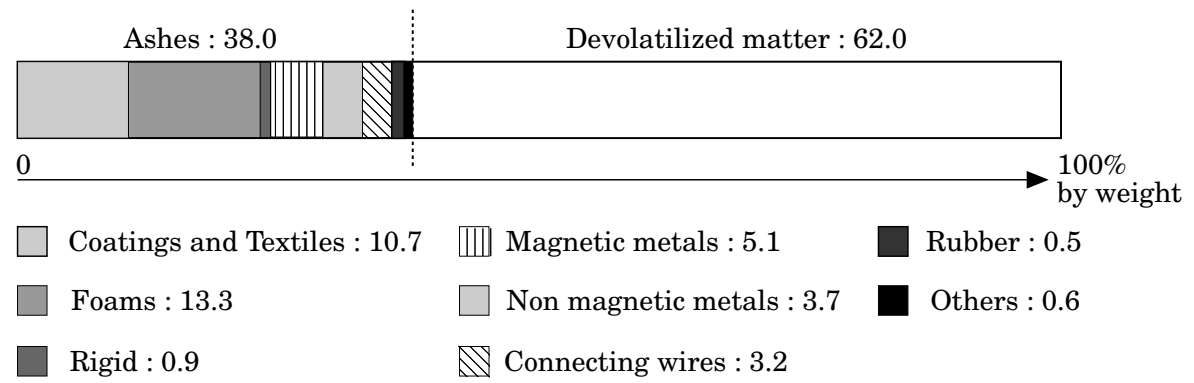

Fig. 8. Results of the ash content determination.

metallic fraction appears as pieces of wiring carried away with the fraction and also as metallic dust deposited on the plastic surface or inside the pores.

\subsection{Specific energy determination}

The results are presented in Fig. 7. The value of $19000 \mathrm{~kg}^{-1}$ is very close to that usually found for a dry wood. This value is high enough to allow energy recovery. A similar value for high specific energy of automotive shredder residues $\left(19900 \mathrm{~kg}^{-1}\right)$ is found in the literature (Druckerei 1988).

The results of these experiments show that the plastic fraction is the largest potential source of energy of ASR. Representing just $2.6 \%$ of the ASR by weight, rubber would generate $4.4 \%$ of the energy produced. Thus, the heavy fraction offers the possibility of energy recovery.

\subsection{Ash content determination}

The results of the ash content determination are presented in Fig. 8. An effective mass loss of $62 \%$ is obtained. The plastic fraction is well reduced but the metallic fraction remains untouched. Only connecting wires lost part of their weight due to the destruction of plastic insulation. Results available from the literature (Druckerei 1988) correspond $(60 \%)$ to the results of these trials. 


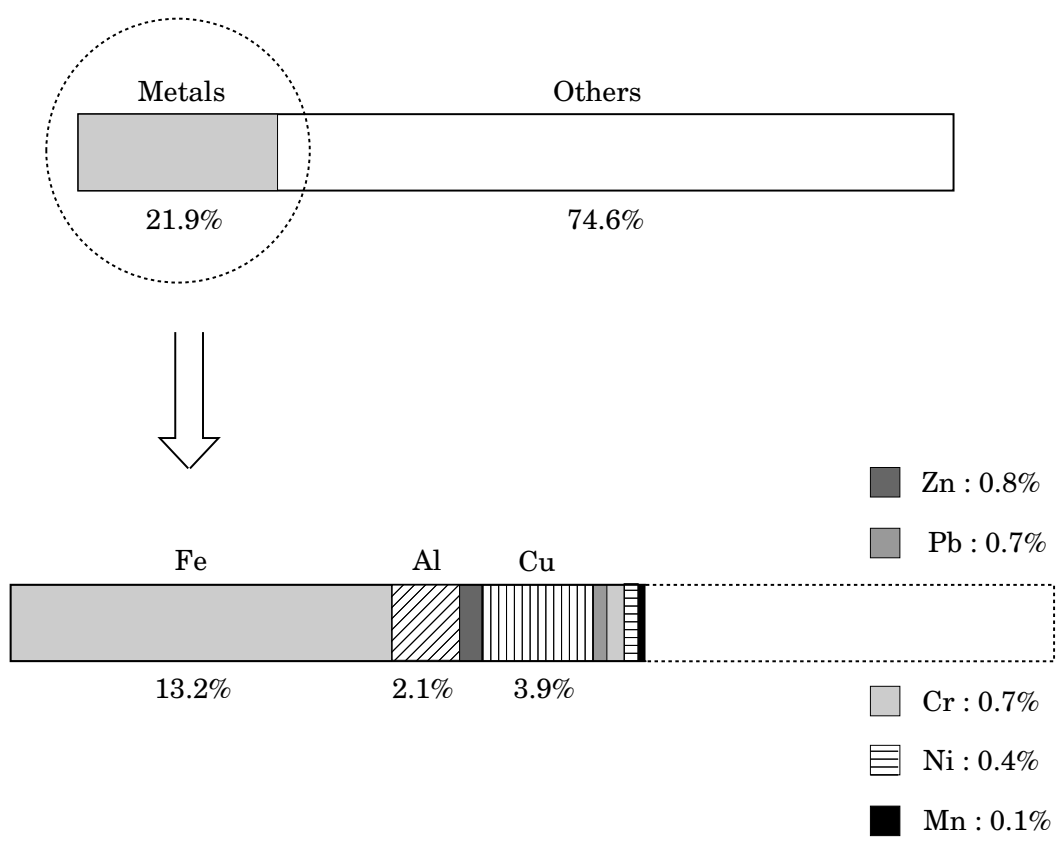

Fig. 9. Results of the heavy metal content determination.

\subsection{Chlorine content determination}

The results of the chlorine content determination of the first fraction of ASR indicate a total concentration of $3.5 \%$. This total content was sufficient to require additional studies on the fate of chlorine during ASR incineration. In fact, chlorine generation has a negative effect in the combustion process; large amounts of hydrogen chloride can be emitted as well as noxious and carcinogenic chlorinated organic compounds (up to $1 \mathrm{~g} \mathrm{Nm}^{-3}$ of $\mathrm{HCl}$, up to $12 \mathrm{ng} \mathrm{Nm}^{-3}$ of polychlorodibenzodioxines; Druckerei 1988). Also heavy metals can be more easily volatilized in the presence of chlorine under a chloride speciation (Wu et al. 1993).

\subsection{Heavy metal content determination}

The results obtained are shown in Fig. 9. The quantity of metallic contents $(21.9 \%$ by weight) is higher than those found for the metallic part $(13.5 \%)$ in the macroscopic composition determination. This fact can easily be explained.

Three kinds of metallic source which were previously described are present in the ASR:

(1) First, metallic constituents could be produced from visible metallic pieces mixed with plastics and rubber. They represent $13.5 \%$ of the total weight as found from the macroscopic composition determination.

(2) Second, during the crushing process, metallic dust such as iron oxide was scattered and finally coated as a thin film onto the non-metallic pieces.

(3) Finally, metallic contents could be produced from metallic components added to polymeric materials to obtain some specific properties. They can be used simply as 
catalysts of polymerization, or as stabilizers to protect against moisture and sunlight, or as flame retardants. Alkali compounds are often used just as mineral charges.

Metal by-products are used in car manufacturing. Iron is generated from steel and ferrous oxide while chromium, nickel and manganese are used to produce special steel. Mechanical pieces that need to be light are often made out of aluminium. Copper comes essentially from electric wires and zinc is generated from mechanical pieces or from the galvanizing steel sheets. In the absence of the battery, the presence of lead can be attributed to the use of leaded fuel, since lead constituents may remain in the engine, muffler (silencer) and solders.

\section{Conclusions}

The macroscopic composition determination of the fluff (fraction No. 1) shows that the principal components of light ASR residues were plastics and metals. The metals found in the majority were iron, aluminium and copper.

With a high specific energy of $19000 \mathrm{~kJ} \mathrm{~kg}^{-1}$ and an ash content of $38 \%$, this study demonstrates that ASR incineration is feasible. It is possible to decrease the mass and the bulk of waste and at the same practice energy recovery. Incineration of ASR in laboratory-scale experiments is the first step to this approach. Considering the results of this characterization (metal contents of $21.9 \%$ and chlorine content of $3.5 \%$ ), one may predict the necessary operating conditions for incineration to avoid toxic emissions (hydrogen chloride, heavy metal chlorides, volatile organic compounds and others). For that purpose, it is now necessary to analyse and quantify gaseous effluents from the incineration of ASR on the laboratory scale.

\section{Acknowledgements}

The authors thank RENAULT S.A. and ADEME for their financial support.

\section{References}

De Macedo, J. R. (1984) Etude sur la valorisation des stériles de broyage d'épaves automobiles (Study of the resource recovery of automotive shredder residues) Rapport A.N.R.E.D., France.

Druckerei, H. (1988) Untersuchung über das Emissionsverhalten der Leichtmüllfraktion aus Autoshreddernalangen beim Verbrennen (Study of effluents emitted during the incineration of the light fraction of automotive shredder residues) Forschungsvereinigung Automobiltechnik EV, F.A.T. Schriftenreihe, Nr. 72.

French Framework Agreement (1993) On the Reprocessing of Scrap Vehicles Paris, 10 March 1993.

Lanoir, D. (1994) Caractérisation physico-chimique des Résidus de Broyage Automobile-Analyse des effluents gazeux émis au cours de leur incinération en vue d'une valorisation énergétique, (Physical and chemical characterization of automotive shredder residues - analyses of gaseous effluents emitted during the A.S.R. with the aim of heat recovery) Doctorat de l'Université de Haute Alsace, Ph.D. dissertation July the first 1994, Mulhouse, France.

Lenga, R. E. \& Votoupal, K. L. (1993) The Sigma-Aldrich Library of Regulatory and Safety Data. 1st Edition, Milwaukee, U.S.A.

Wu, C. Y. \& Biswas, P. (1993) An equilibrium analysis to determine the speciation of metals in an incinerator. Combustion and Flame 93, 31-40. 